\title{
HISTORY OF COMPARATIVE DIALECT STUDIES
}

\author{
Madina Nosirovna Musurmankulova
}

Teacher, Independent Applicant, Russian Language At The Denau Institute Of Entrepreneurship And Pedagogy, Uzbekistan Djamshid Berdimurotovich Boymirzayev

Student, Denau Institute Of Entrepreneurship And Pedagogy, Uzbekistan

Djahongir Musulmonovich Norbadalov

Student, Denau Institute Of Entrepreneurship And Pedagogy, Uzbekistan

\section{ABSTRACT}

This article discusses the dialect system of the Russian and Uzbek languages in a comparative aspect.

Studying the dialect system of the Russian and Uzbek languages in a comparative aspect makes it possible to create a comparative dialectological competence. This article is devoted to the creation of dialectological competence at the comparative level of different languages. In long-distance areas dialects, dialect systems and folklore still exist. Improving the system of comparative dialect competence of the Russian and Uzbek languages at present can give a methodical direction to students of the national group. A competent approach to the study of the dialect system develops the knowledge of future Russian language teachers in national schools. Dialect words in both the Uzbek language and the Russian language are considered in a semantic aspect.

KEYWORDS: - Dialect words, competence, type, national group, subtypes, comparative-dialectological competence, concept, semantics.

\section{INTRODUCTION}

The requirements for the competence of faculty are changing with the advent of new components in terms of the demands of the times. In addition, the qualification requirements for the competence of teachers are set out in international legal documents, and their creative and effective use plays an important role in improving the competence of education managers in accordance with international requirements [8, p.40]

"The Concept of development of the higher education system of the Republic of Uzbekistan until 2030" defines that "improving the quality of training highly qualified personnel, developing human capital based on the requirements of the labor market for modernization and stable socioeconomic development of the country" [1, p. 7]. In the regulation of the Cabinet of Ministers of the Republic of Uzbekistan on measures to improve the system of professional training of qualified personnel in demand in the labor market, it is determined that, at the same time, solving the problems in this area necessitates the creation of an effective system for training highly qualified blue-collar professionals, taking into account the needs of the labor market, including large enterprises and clusters created locally 
CURRENT RESEARCH JOURNAL OF PHILOLOGICAL SCIENCES 2(6): 55-60,

May 2021 DOI: https://doi.org/10.37547/philological-crjps-02-06-12

ISSN 2767-3758

(C)2021 Master Journals

Crossref do: 81 Google

Accepted23thJune, 2021 \& Published 28thJune, 2021

"[2].

Currently, a professional teacher is required with highly developed educational-key competence, freely orienting in different circumstances, contributing to the addiction of students to an international culture, by promoting their awareness of their own national culture [12, p. 224].

Communicative behavior is not only determined in the modern environment, but even in remote areas.

\section{Methods}

In the sphere of his activity, every teacher or teacher faces such problems, sometimes in schools there are students, and in higher educational institutions when students receive an assignment, but after reading it, they cannot understand what its essence is; cannot apply a certain set of facts. This is a typical situation for students from a national group, when students can master a set of theoretical knowledge well, but experience significant difficulties in using this knowledge to solve specific problems, to extract the main thing from what they have read or listened to, and others require a transition to a new degree of competence-based learning [12, p. 224].

Competence is a characteristic of a person, and competence is what he already owns (ability, skill). It is what he owns that defines his characterization as competent. We can use these two terms as synonyms in two basic meanings knowing, in the sense of being able and in the sense of the skills that he possesses, and also capable, in the sense of having a certain potential, the ability to carry out his actions [12, p. 224].

The Council of Europe identifies 5 basic competencies required today by any specialist, including a teacher: political and social; competencies related to life in a multicultural society; competencies related to the emergence of the information society; competencies that realize the ability and desire to learn throughout life; ... [11, p.5].

Competence is the ability to successfully respond to individual or social requirements, to conduct activities. From the text, we can understand that competence must meet individual and social requirements. In other words, it should allow one to obtain individually or socially significant knowledge or results.

Competence is:

1. Knowledge, experience, skills.

2. The circle of problems and problematic issues in which the knowledgeable can have information about everything.

3. A set of problems in relation to which a person has wide knowledge and experience in solving [12, p. 225].

The focus on competence-based education was formed already in the 70s. XX century in America in the context of the concept of "competence" proposed by $\mathrm{N}$. Chomsky in relation to transformational grammar. Chomsky writes: “... we make a fundamental distinction between competence (the speaker's knowledge of his / her language) and use (the actual use of the language in specific situations). Only in an idealized case ... use is a direct reflection of competence. " Let's pay attention to the fact that "use", according to Chomsky, is a manifestation of competence as something potential, that is, use is associated with skills, thinking, the speaker himself, his experience [6, 240 p.].

In dictionaries and scientific literature, "competence" is explained in different ways:

Theoretical and applied readiness to use knowledge; knowledge, skills, experience,

the range of issues in which the individual is well 
CURRENT RESEARCH JOURNAL OF PHILOLOGICAL SCIENCES 2(6): 55-60,

May 2021 DOI: https://doi.org/10.37547/philological-crjps-02-06-12

ISSN 2767-3758

(C)2021 Master Journals

\section{Crossref do) 8 Google}

Accepted23thJune, 2021 \& Published 28thJune, 2021

aware;

collection of questions in which this person has knowledge and experience of his own activities.

Competencies are interpreted as a single (coherent) language to describe academic and professional profiles and levels of higher education. It is sometimes said that the language of competences is the most appropriate for describing the results of education. The orientation of standards, curricula (educational programs) on educational results makes qualifications comparable and transparent, which cannot be said about the content of education, which is strikingly different not only between countries, but also between universities, even when training in the same specialty (subject area) ... So far, no more modern methodological tool for "Bologna" renewal has been found in European universities of curricula and programs. The results of education, expressed in the language of competencies, according to Western experts, are a way to expand academic and professional recognition and mobility, to increase the comparability and compatibility of diplomas and qualifications. In the conditions of Russia, the implementation of the competence-based approach can act as an additional factor in maintaining a single educational, vocational qualification and cultural value space [3, p. 6.]

General and professional competences form a kind of complementary unity. General (key, universal) competencies, according to prof. Yu. Kohler, should be a pedagogically expedient tool for increasing employability and didactic quality proper [5].

Today, there are many basic concepts of "competence", "key competencies". Therefore, the problem of studying various approaches and their systematization is actualized [12, p. 225].

Studying the comparative-dialectological competence of the future, teachers get the opportunity to master the methodology of working with dialectal speech, learn to distinguish between dialectal and individual characteristics of speech, develop the ability to see dialectal and dialectal - individual characteristics in the speech of representatives of the younger generation [12, p. 225].

We know that in remote areas there are still dialects, dialect systems, folklore. Improving the system of comparative dialect competence of the Russian and Uzbek languages at present can give a methodical direction to students from the national group.

".......at the same time, it is necessary to deeply study the features of the Uzbek language and its dialects, issues related to its history and development prospects, increase the efficiency of specialized scientific research, and radically improve the quality of personnel training" [Shavkat Mirziyoyev, Gazeta.uz.] [12, p. 225].

Thus, comparative dialectological competence is aimed at solving a number of educational and pedagogical problems [12, p. 226].

What is a dialect? What is the history of the dialects of the Uzbek and Russian languages? Scientists studying dialect systems of Russian and Uzbek languages? [12, p. 226].

F.P. Filin defines a dialect word as "a word that has a local distribution and at the same time is not included in the vocabulary of the literary language (in any of its varieties)." [9, p.556].

All natural languages existing in the world have national borders, therefore, one of the main in modern linguistics is the concept of a national (common) language, which is the language of a particular people in the aggregate of all its inherent features that determine it as such and differentiate it from other languages [7, 416 p.]. Creating a dialectological atlas can show the distinguishing features of two languages [9, 
CURRENT RESEARCH JOURNAL OF PHILOLOGICAL SCIENCES 2(6): 55-60,

May 2021 DOI: https://doi.org/10.37547/philological-crjps-02-06-12

ISSN 2767-3758

(C)2021 Master Journals

\section{Crossref do) 8 Google}

Accepted23thJune, 2021 \& Published 28 ${ }^{\text {th }}$ June, 2021

p.557].

A.I. Sobolevsky in 1892 for the first time introduced the teaching of Russian dialectology as an independent discipline at universities, giving a course of lectures on it. And already in 1897 a separate textbook appeared, entitled "Experience of Russian dialectology." In it, on the basis of the collected materials, Sobolevsky tried to identify the main units of dialect division, to determine the territory of these units and to name their characteristic features. Sobolevsky introduced into scientific use all the material collected from the dialects of the Russian language [9, p.558].

It can be said that the dialectological map of the comparative system provides such information that can be developed by future teachers of the Russian language integration knowledge [9, p.558]. I. I. Sreznevsky was the first scientist who in 1852 raised the question of creating a map on which the boundaries of languages, dialects and dialects of the Russian language would be indicated. At this time, V. I. Dahl was engaged in the study of dialect vocabulary, who was interested in the dialects of the Russian language in terms of their origin and classification [9, p.558].

Dialecticism can be interpreted as a word used only in a certain territory within the boundaries of any adverb and absent in another dialect and in the literary language. Modern dialectology distinguishes the following types of dialectisms: a) grammatical dialectisms - words that have different grammatical characteristics from the literary language, manifested in a different declension, a special formation of forms of parts of speech, the transition from one grammatical gender to another, etc.: past the hut (instead of past the hut), in the steppe (instead of in the steppe), wide steppes (instead of wide steppes), weaker (instead of weaker). The whole face seems to have become blue (I. Bunin). The cat smells whose meat it has eaten (A. Sholokhov); b) phonetic dialectisms - words with a different pronunciation of certain sounds and sound combinations than in the literary language: girl, shout, tsai (tea), nyasu, ball, chicken (chicken), barrel (barrel); c) semantic dialectisms - general literary words with a different meaning than in the literary language: much (very), impudent (sudden), flood (drown), guess (recognize by sight), top (ravine); ( side); e) lexical dialectisms - local names of objects and phenomena that have other names in the literary language: bases (covered yard for cattle), beetroot (beet), veksha (squirrel), gashnik (belt), deja (kvashnya), zakut or zakuta ( small cattle shed), at once (now), cochet (rooster), stubble (stubble); g) ethnographisms - local names of local objects: a diner, a coastal worker, a midwife, a shalonik, (names of winds among the Pomors), a crane (a lever for raising water from a well), cats (birch bark bast shoes), novina (a stern canvas) [10, p. 119-120].

Complex concepts also exist in the system of Uzbek dialectisms. Many ethnic groups took part in the ethnogenetic processes of the Central Asian interfluve, among which were speakers of both East Iranian languages and Oguz, Karluk, and Kipchak dialects [9, p.556].

In a comparative aspect, it is possible to create a system of dialectological competence [12, p. 227].

Dialectology of the Uzbek language - the study of the dialectic picture of the modern Uzbek language. The modern Uzbek language is characterized by a significant dialect branching, which is due to the complex ethnogenesis of the Uzbek people [9, p.556]. The Uzbek dialects are subdivided by researchers into three main dialects, which were given different names: 1) Middle Uzbek (southeastern, Chagatai, or Karluko-Chigile-Uighur); 2) South Khorezm (southwestern, or Oguz); H) northwestern 
CURRENT RESEARCH JOURNAL OF PHILOLOGICAL SCIENCES 2(6): 55-60,

May 2021 DOI: https://doi.org/10.37547/philological-crjps-02-06-12

ISSN 2767-3758

(C)2021 Master Journals

\section{Crossref do) 8 Google}

Accepted23thJune, 2021 \& Published 28thJune, 2021

(Kypchak, Sheybanidouzbek, OR dzhekaye). E. D. Polivanov, who was the first to outline this division, marked the difference between these adverbs with three phonetic signs using examples of two words: 1) tag, sart, $q \bullet, 2$ ) daq, sarb (sa: rb) •, H) daq, sarb ... A. K. Borovkov, keeping basically the same division, lists the features of each adverb separately. To demarcate the "Sheibanid-Uzbek, or Jacking, dialect", he gives eight signs, two of them are morphological [4, p.55].

Due to the close proximity and the closest ethnocultural contacts, the Uzbek language has been influenced by the significant influence of the Tajik language [9, p.556].

In turn, the Uzbek language had a huge impact both on the Tajik language and on the Turkic languages of the region [9, p.556].

Scientific and practical features of comparative dialectological competence is primarily in the accumulation of valuable materials in Russian and Uzbek dialects. This information is not only of its own interest, but also serves as an important source for studying the history of the Russian and Uzbek languages, the history of the people, the ethno-dialectal division of the Russian and Uzbek territories [12, p. 225].

A competent approach to improving the comparative dialectological system has an important place in integrating the education of future teachers of the Russian language [9, p.556].

As a result, the future of Russian language teachers should know: the peculiarities of the dialectal division of the modern Russian and Uzbek languages;

In general, in the process of improving this system, as mentioned above, in a comparative aspect, within the functioning of the Russian and Uzbek languages, one can keep in mind such features as each language has its own national mentality and individual sides in folklore [9, p.556], linguistic features of the system of Russian-Uzbek dialects; the originality of the material and spiritual culture of the population in a comparative aspect [12, p. 225].

Tasks of comparative dialectological competence:

- educational and methodological tasks mastering the methods of analyzing dialectal phenomena; deepening and expanding knowledge of Russian and Uzbek dialectology;

- professional tasks - acquisition of basic skills in comparative dialectology;

- scientific and practical tasks - the development of future teachers of interest in research work; formation of a scientific approach to working with linguistic material [12, p. 225].

\section{Conclusion}

The improvement of the system of comparativedialectal competence of the Russian and Uzbek languages at the present time can provide a methodological direction for students from the national group. A competent approach to the study of the dialect system develops the knowledge of future teachers of the Russian language in national schools. Comparative dialectological competence is interconnected with both linguistic (linguistic) and communicative competence. The main direction of sociolinguistics [12, p. 228].

Comparative dialectological competence gives a certain direction in training personnel for further professional and pedagogical activity, since knowledge of dialects, on the one hand, helps to develop ideas about the richness and diversity of the Russian and Uzbek languages, and on the other hand, it allows to carry out productive work on reporting errors in speeches of representatives in the local dialect of Russian and Uzbek languages [12, p. 228]. 
CURRENT RESEARCH JOURNAL OF PHILOLOGICAL SCIENCES 2(6): 55-60,

May 2021 DOI: https://doi.org/10.37547/philological-crjps-02-06-12

ISSN 2767-3758

(C)2021 Master Journals

Crossref do: 81 Google

Accepted23thJune, 2021 \& Published 28thJune, 2021

\section{REFERENCES}

1. Decree of the President of the Republic of Uzbekistan on the approval of the concept of development of the higher education system of the Republic of Uzbekistan until 2030, p.7.

2. Resolution of the Cabinet of Ministers of the Republic of Uzbekistan on measures to improve the system of professional training of qualified personnel in demand in the labor market. -National database of legislation, 14.05.2019, No. 09/19/394/3125.

3. Baydenko V. I. Revealing the composition of the competencies of university graduates as a necessary stage in the design of the state educational standard of higher education of a new generation. Toolkit. - M.: Research Center for the Problems of the Quality of Training of Specialists, 2006. - 72 p.

4. Zhirmunskiy VM, On some questions of linguistic geography of the Turkic dialects. Publishing house "Science", M.-1960. , p.55.

5. Kohler Jürgen, Universität Grecfswald. Schlüsselkompetenzen und "employability" in Bologna Prozess. Konferenz Schlüsselkompetenzen: Schlüssel $\mathrm{zu}$ mehr (Aus.) Bildungsqualität und Beschäftigungsfähigkeit? Heidelberg, 22 und 23 Januar 2004.

6. Minina AI, Actual problems of language competence. 236-242s., 240 p.

7. Mistyuk TL, Zaeskova SV, Tum EA, Some aspects of modern dialectology in the course "Russian language and culture of speech". 416-422 p.

8. Musurmonova O. Pedagogik texnologiyalar ta'lim samaradorligini omili. Yoshlar nashriyoti uyi, T.-2020, p. 183.

9. Musurmankulova M.T., Aminova R.X.,
Xamrayeva U.A. Development of integrative knowledge on comporative-dialectologial competence of future teachers of the Russian language. The American Journal of Social Science and Education Innovations. Doi : https://doi.org/10.37547/tajssei/Volume03 Issue03-89. -2021, p.555-559.

10. Russian language / ed. L. Yu. Maksimova. M .: Education, 1989.287 p., P. 119-120

11. Yarkina TF Western teachers about the development of modern schools, p.5.

12. Musurmankulova M.T., Azizova N.R. SEMANTICS OF COMPETENCE IN PEDAGOGY AND COMPARATIVE DIALECTOLOGIAL COMPETENCE IN RUSSIAN AND UZBEK LANGUAGES. Asian Journal of Multidimensional Research (AJMR)https://www.tarj.in 1ISSN: 22784853 Vol 10, Issue 4, April, 2021 Impact Factor: SJIF 2021= 7.699. 223-229 стр. 